\title{
INVENTORY AND MONITORING OF GROUNDWATER-DEPENDENT ECOSYSTEMS: \\ PROTOCOL IMPLEMENTATION AND RESULTS FOR NATIONAL FORESTS AND GRASSLANDS
}

Tim Stroope

USDA Forest Service

National Groundwater Program, Lakewood, CO

Joe Gurrieri

USDA Forest Service

National Groundwater Program, Lakewood, CO

\section{Kate Dwire}

USDA Forest Service

Rocky Mountain Research Station, Ft. Collins, CO

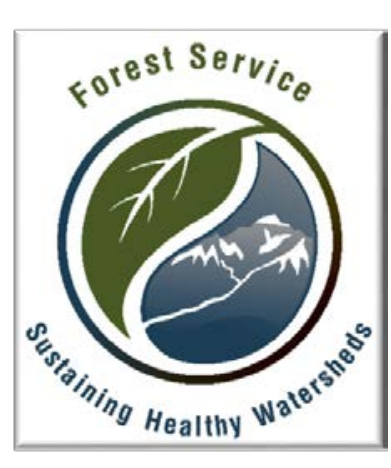

"ning Healthy walo 


\section{Field Guides Published in 2012}

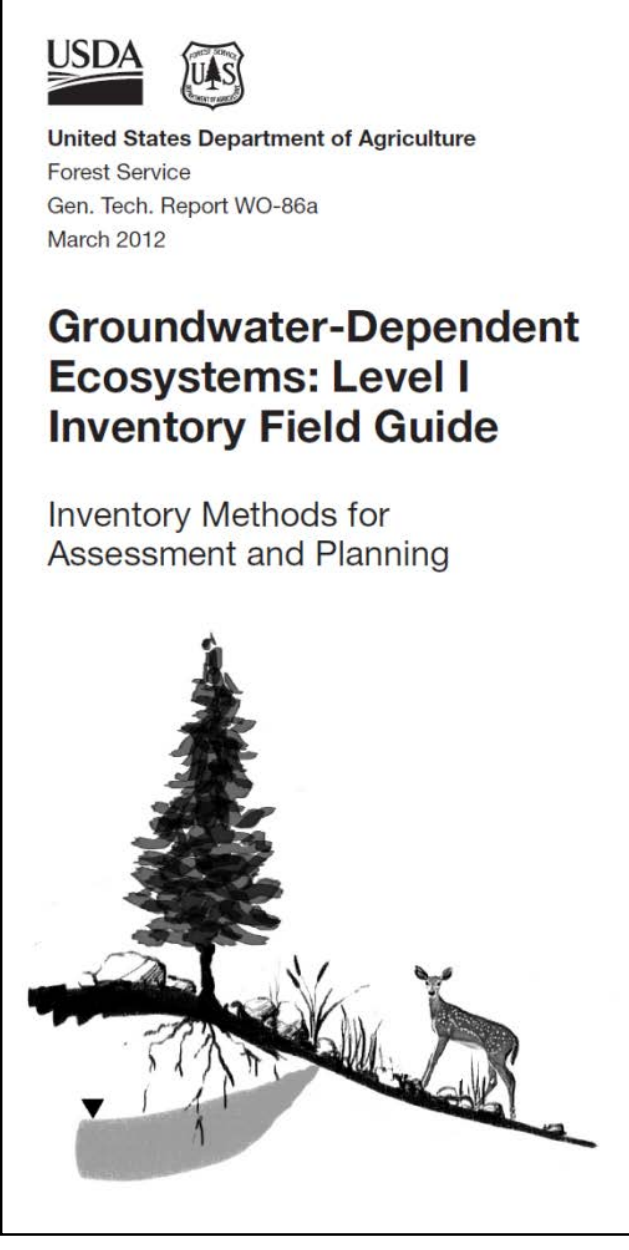

Level I - Qualitatively locate and characterize GDEs

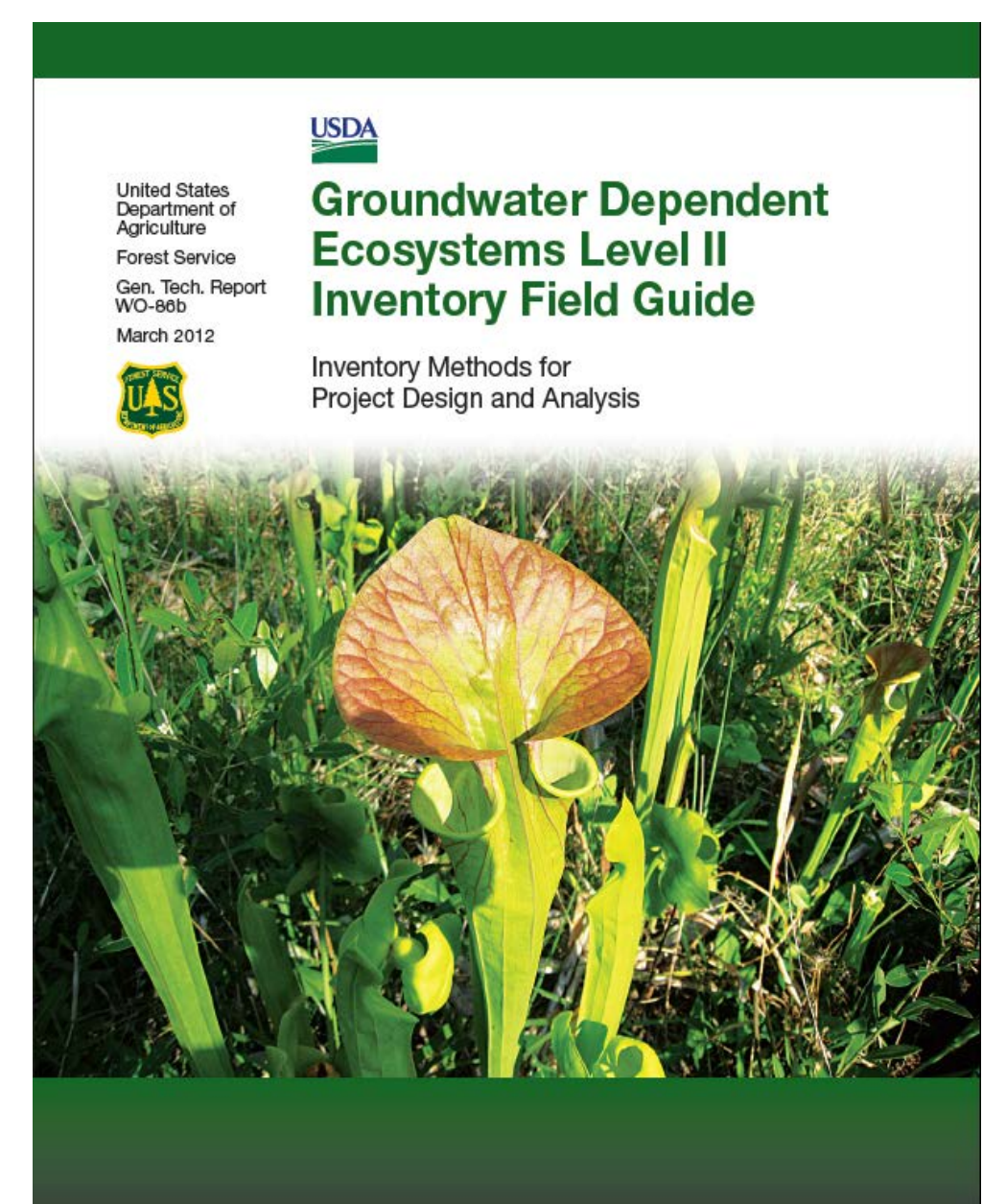

Level II - Quantitatively describe major ecosystem attributes 


\section{Consistent Approach to Inventory and Monitoring}

- Location

- Species: presence/absence

- Baseline conditions

- Alteration

- Decision Making

- Protection or restoration

- Monitoring
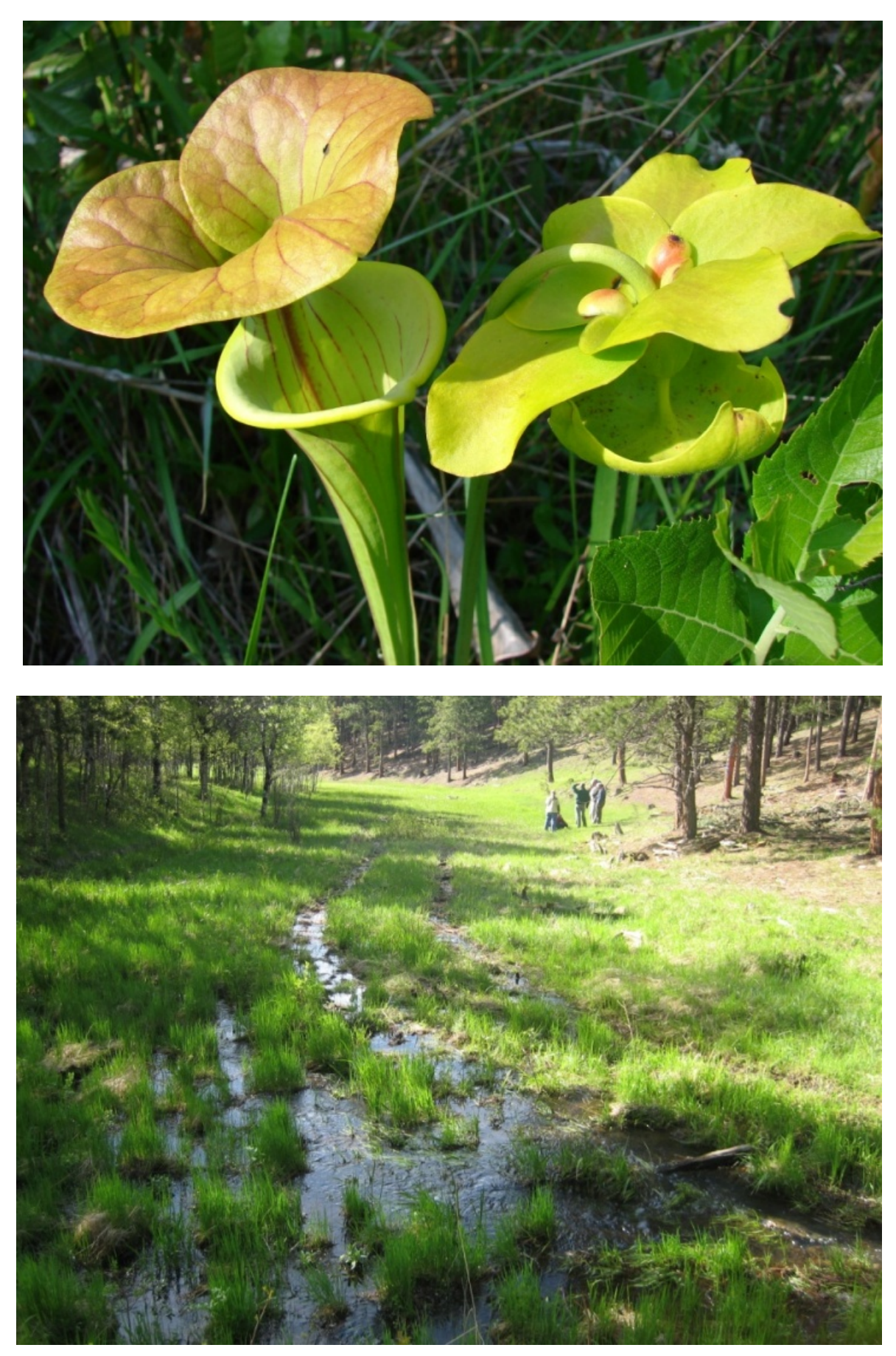


\section{Multidisciplinary}

\section{Approach}

Hydrology
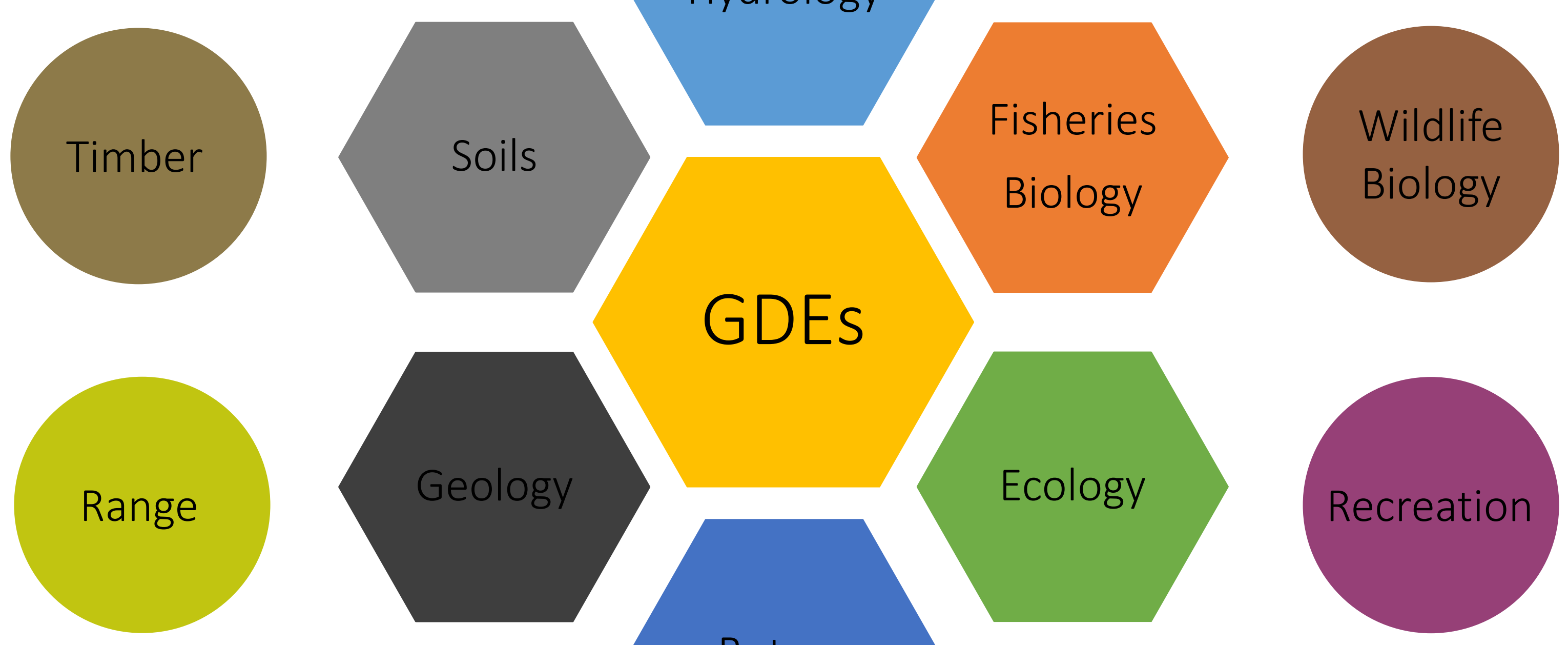

GDES

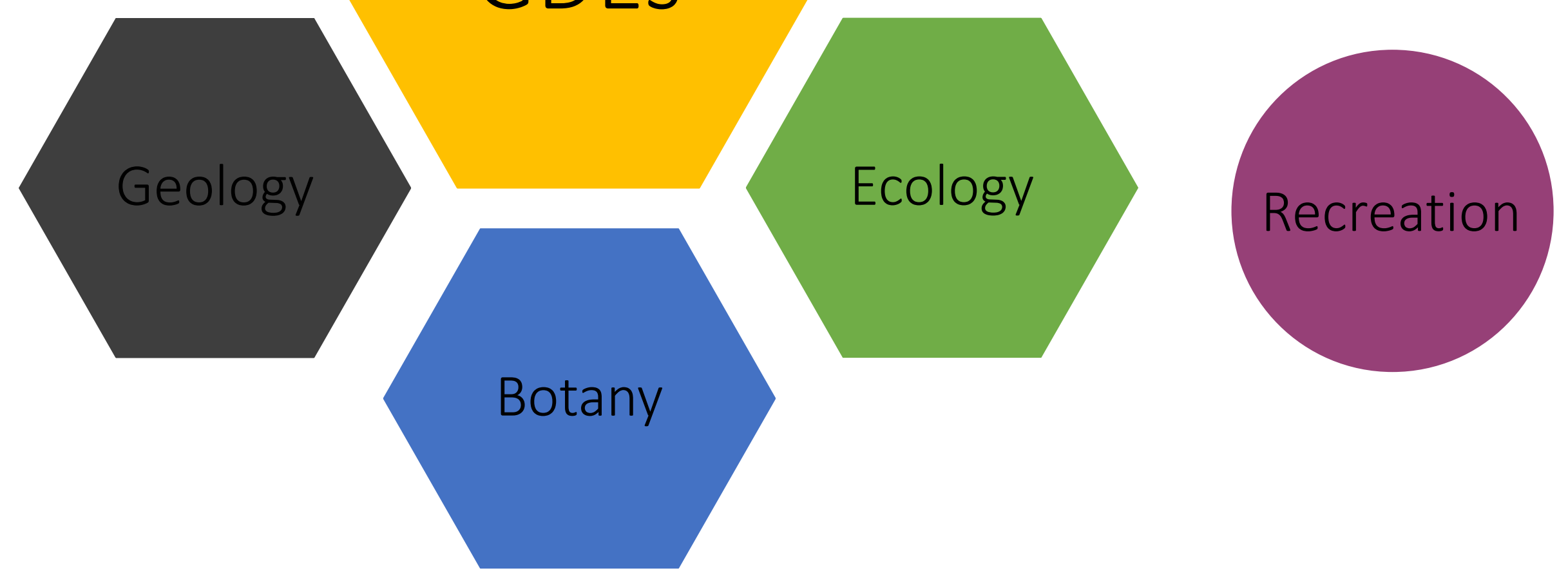




\section{Field Survey - Overview}

- Personnel with skills in botany, soils, hydrology, geology

- Level I: 2-3 people

- Level II: 3-5 people

- Survey time:

- Level I: less than 2 hours/site

- Level II: 3-6 hours/site

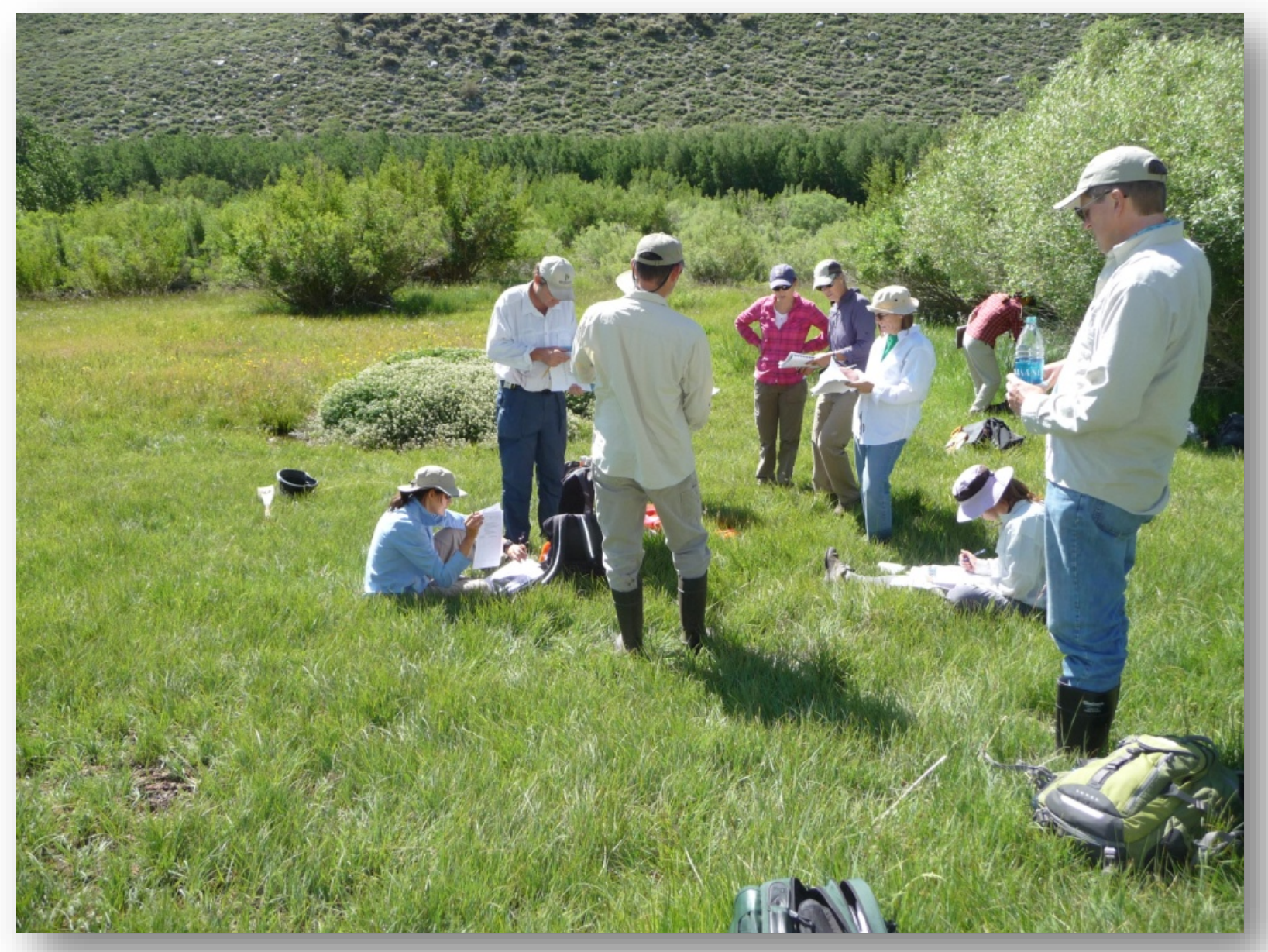


Google Scholar Results for "groundwater dependent ecosystems"

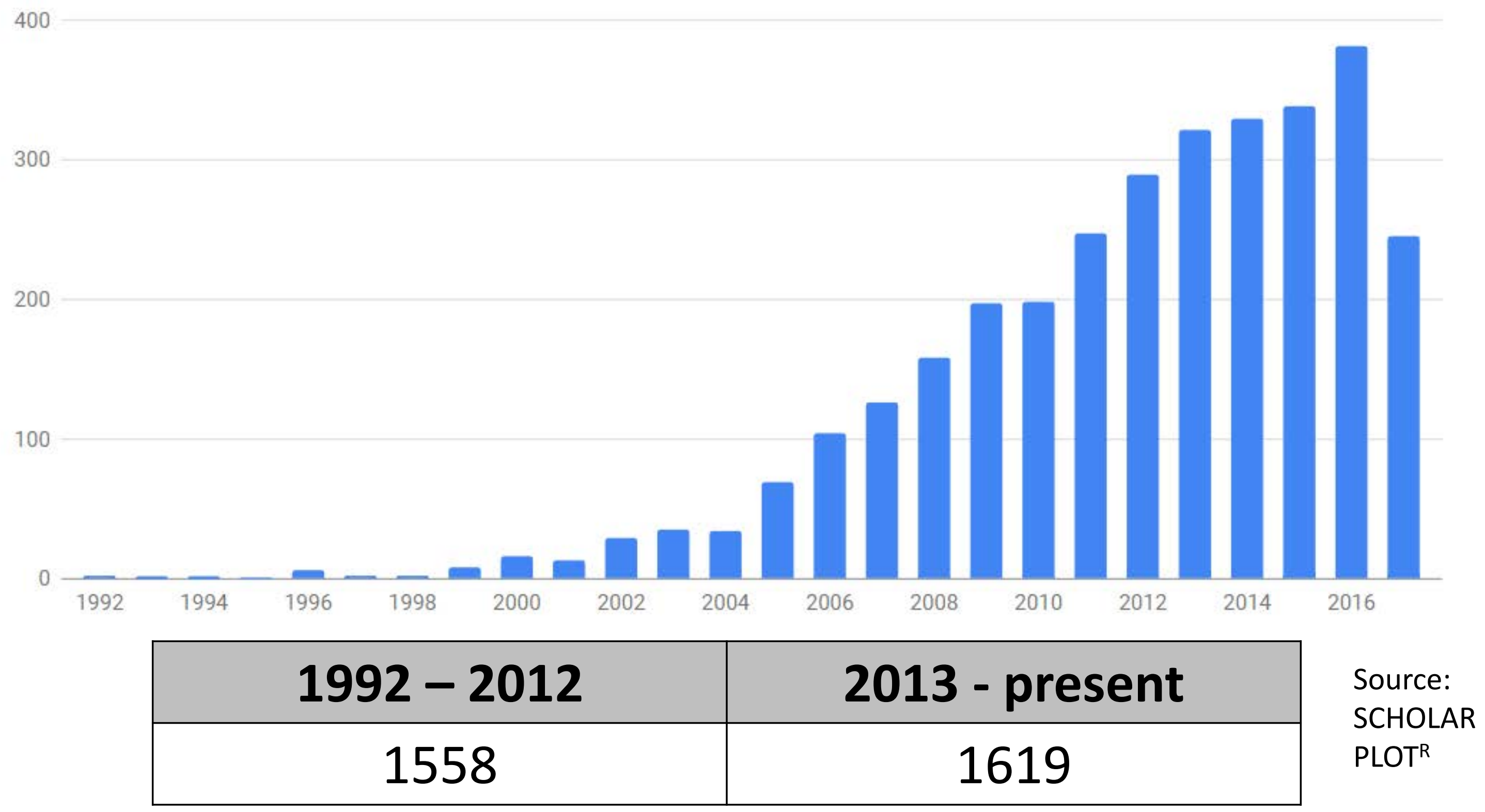




\section{Demands on Groundwater}

- Multiple-Use agency

- Recreation, resource extraction, grazing

- >3,000 communities get drinking water from watersheds on NFS lands

- Atlanta, Denver, Seattle, Los Angeles

Visits (millions) to national forests
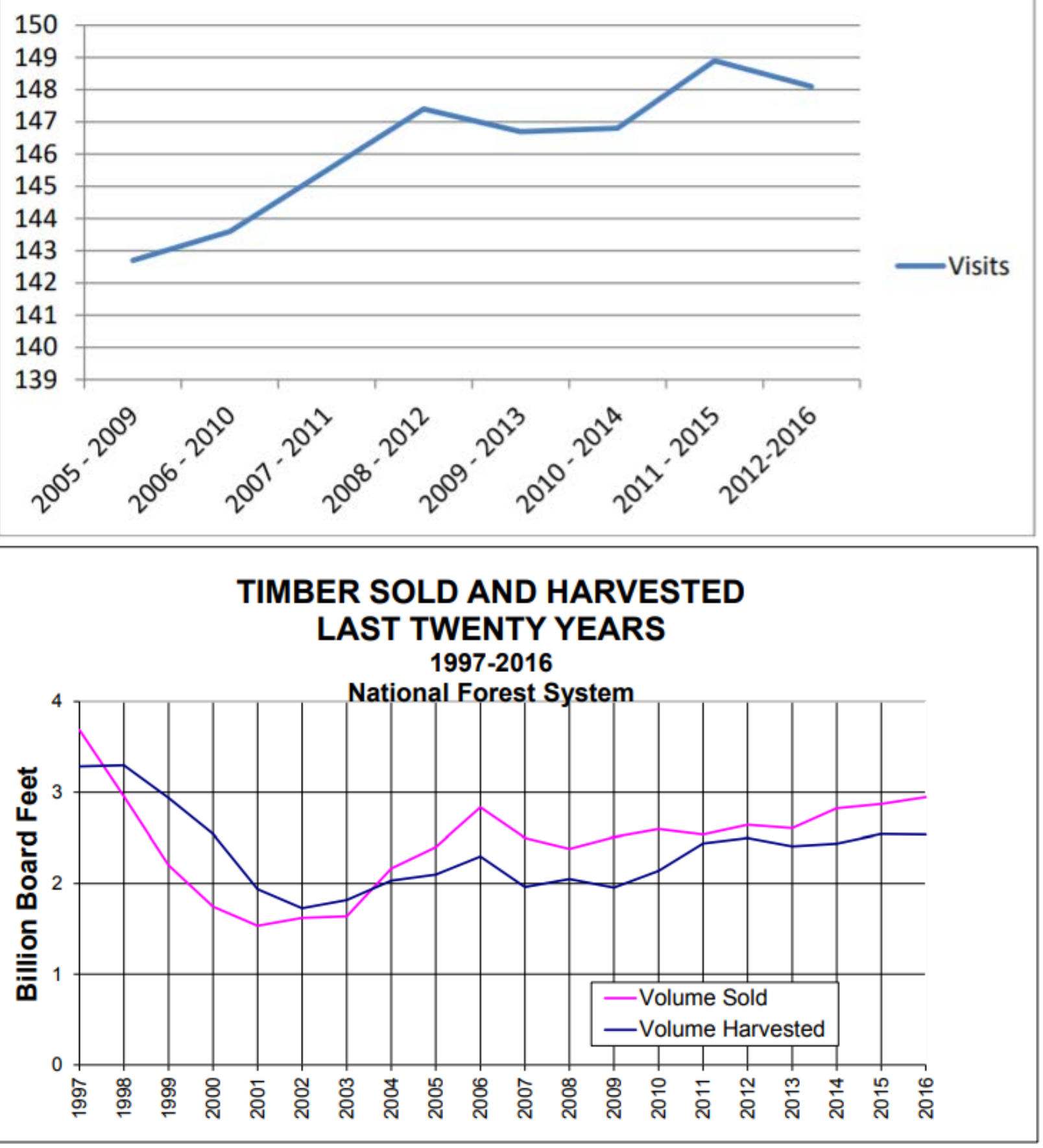


\section{Planning Rule}

- Updated for the first time in 30 years

- Assessment Phase

- Plan development Phase

- Monitoring Phase

- Rule specifically states that a forest plan must include plan components, including standards or guidelines, to maintain or restore water resources, including GDEs 


\section{Montanore Mine}

- Kootenai National Forest, MT

- Underground silver/copper mine

- Base line data collection

- GDE surveys 2009-2013

- Continued monitoring 2010-2014

- Level I and partial Level II

- Surveys contracted

- Determine source of water

- Identified and characterized GDEs in three drainages

Table 97. Flow Measurements and Elevations for Identified Springs in the CMW.

\begin{tabular}{|c|c|c|c|c|}
\hline \hline Spring ID & $\begin{array}{c}\text { Elevation } \\
\text { (feet) }\end{array}$ & Flow Rate (gpm) & $\begin{array}{c}\text { Number of } \\
\text { Measurements }\end{array}$ & $\begin{array}{c}\text { Date Range of } \\
\text { Measurements }\end{array}$ \\
\hline SP-1R & 4,900 & $-0.01-20$ & 10 & $10 / 98-10 / 13$ \\
\hline SP-2R & 4,850 & 4 & 1 & $10 / 98$ \\
\hline SP-4R & 6,490 & 5 & 1 & $9 / 05$ \\
\hline SP-05/3R & 4,200 & 5,22 & 2 & $8 / 98-10 / 98$ \\
\hline SP-16 & 4,600 & $40-50$ (estimated) & 1 & Unknown \\
\hline SP-41 & 5,625 & 27 & 4 & $9 / 07-9 / 13$ \\
\hline SP-42 & 5,400 & 22 & 1 & $8 / 21 / 13$ \\
\hline Spring 8 & 4,360 & 22 & 3 & $9 / 10-9 / 12$ \\
\hline Spring 13 & 4,520 & $1-2$ & 1 & Unknown \\
\hline GDE-1 & $\begin{array}{l}6,588-6,708 \\
\text { (four seeps) }\end{array}$ & No measurable flow & 1 & $8 / 13$ \\
\hline GDE-2 & $6,747-6,825$ & $<2$ & 1 & $8 / 13$ \\
(five seeps) & 5,703 & $<10$ & 1 & $8 / 13$ \\
\hline GDE-3 & 5
\end{tabular}

gpm $=$ gallons per minute.

Source: Geomatrix 2006b, 2006d, 2009a, 2010b, 2011c; NewFields 2013a; MMC 2014d; Klepfer Mining Services 2015a; McKay, pers. comm. 2007; September 2007 agencies' field review of Rock Lake area. 
- Upper Libby Creek

- Springs and seeps support wetlands with diverse vegetation

- Upper East Fork Rock Creek

- Seeps run over bedrock

- Limited wetland vegetation established

- East Fork Bull River drainages

- Large seep/pond/wetland

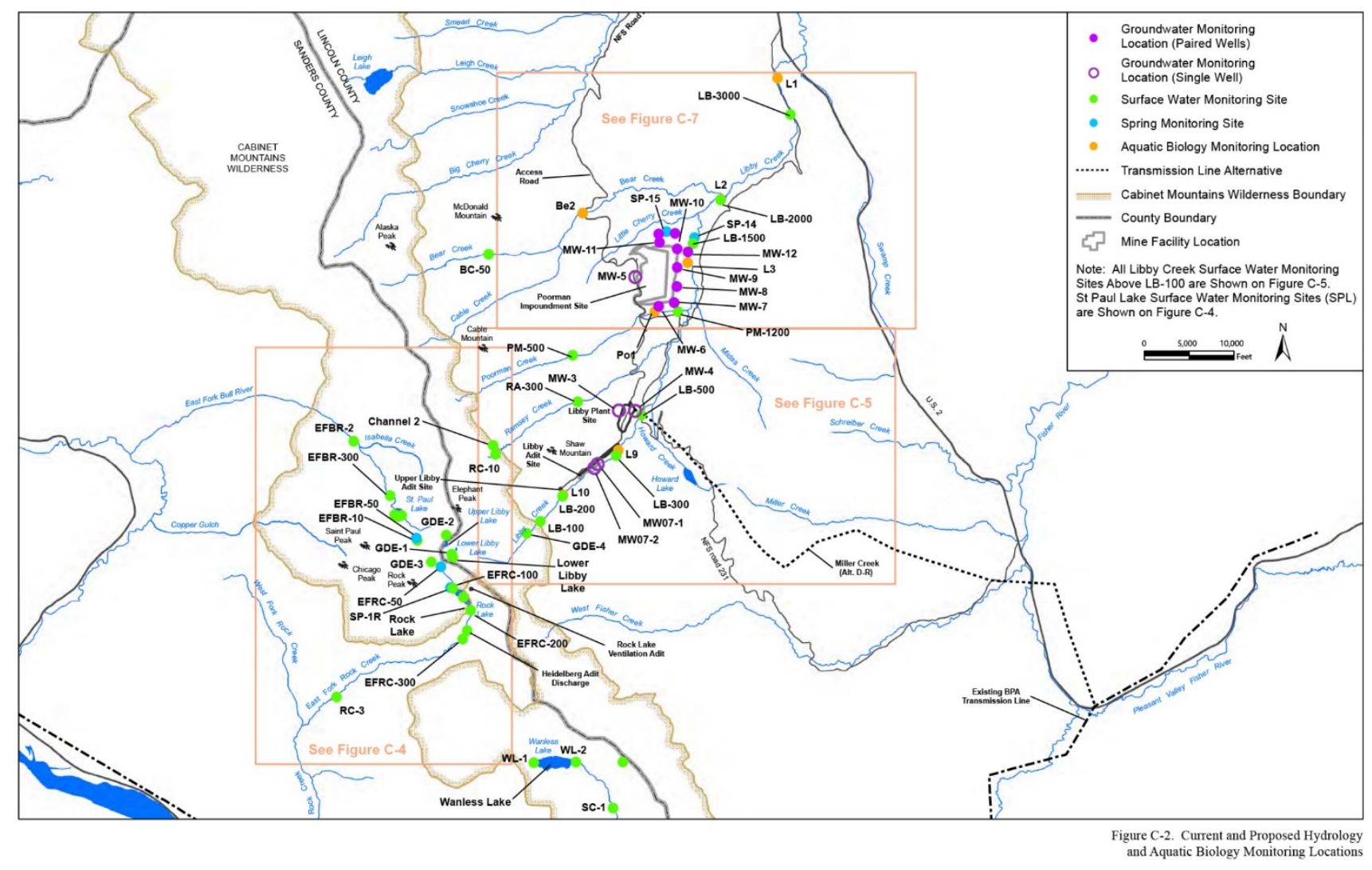
complex

- Future monitoring could use Level II to rank GDEs in importance of supporting critical habitat 


\section{Blue Mountains Climate Assessment}

- Umatilla, Malheur and WallowaWhiteman NFs, OR

- Develop restoration priorities and identify more vulnerable GDEs

- Blue Mountains Resiliency Project and Blue Mountains Forest Plan Revision in process

- Opportunity for "complete" Level I inventories?

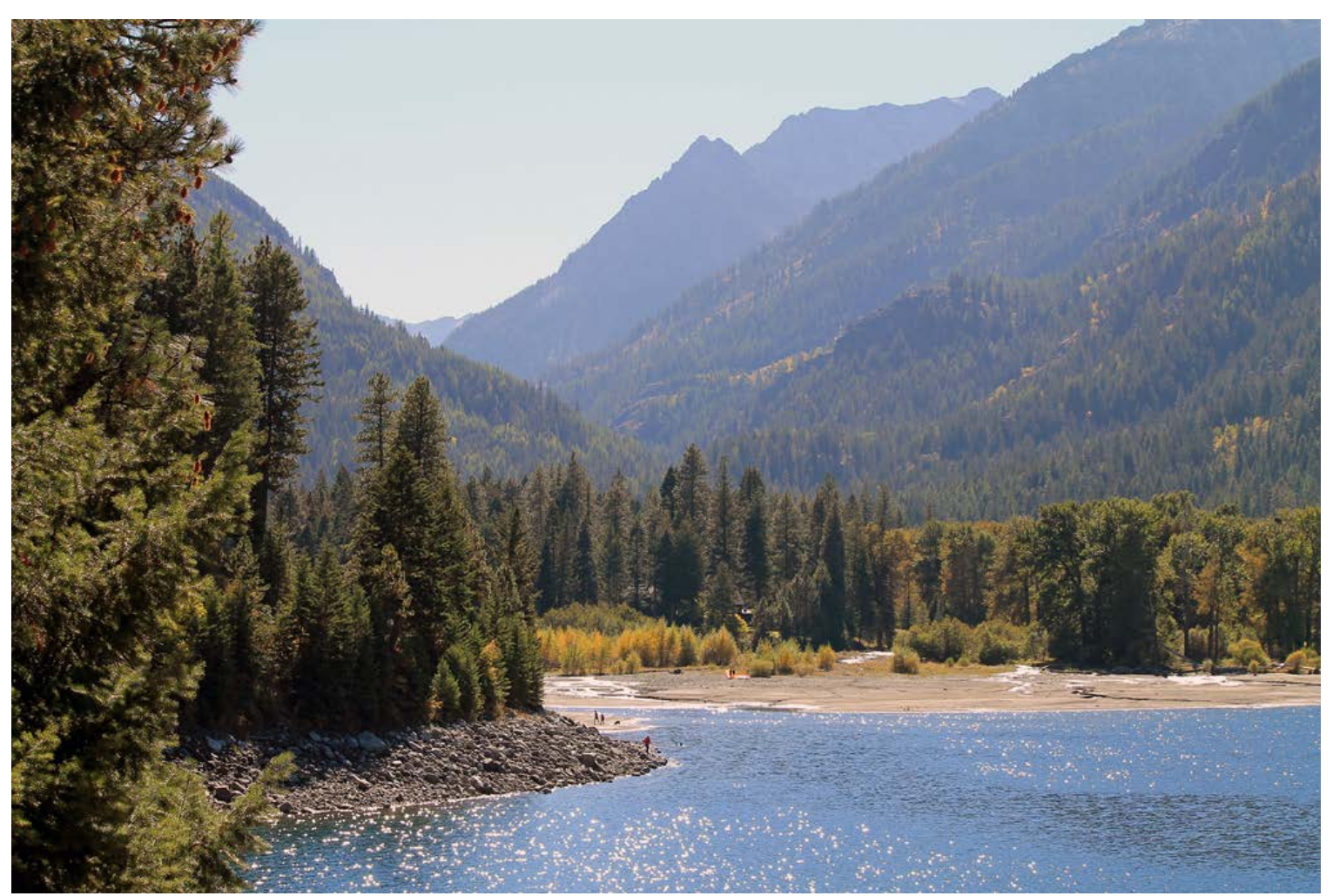


- 133 GDEs inventoried using Level I since 2008

- Umatilla NF: Targeted portions of grazing allotments and watersheds with specific management concerns

- $56 \%$ of GDEs had reduced aquifer functionality

- $24 \%$ of GDEs had soil alteration

- $18 \%$ of GDEs had higher than expected upland species cover

- Many water diversions

- On average $93 \%$ of available water diverted

- Malheur and Wallowa-Whiteman had similar patterns 


\section{Black Hills NF Resilient Landscapes Project}
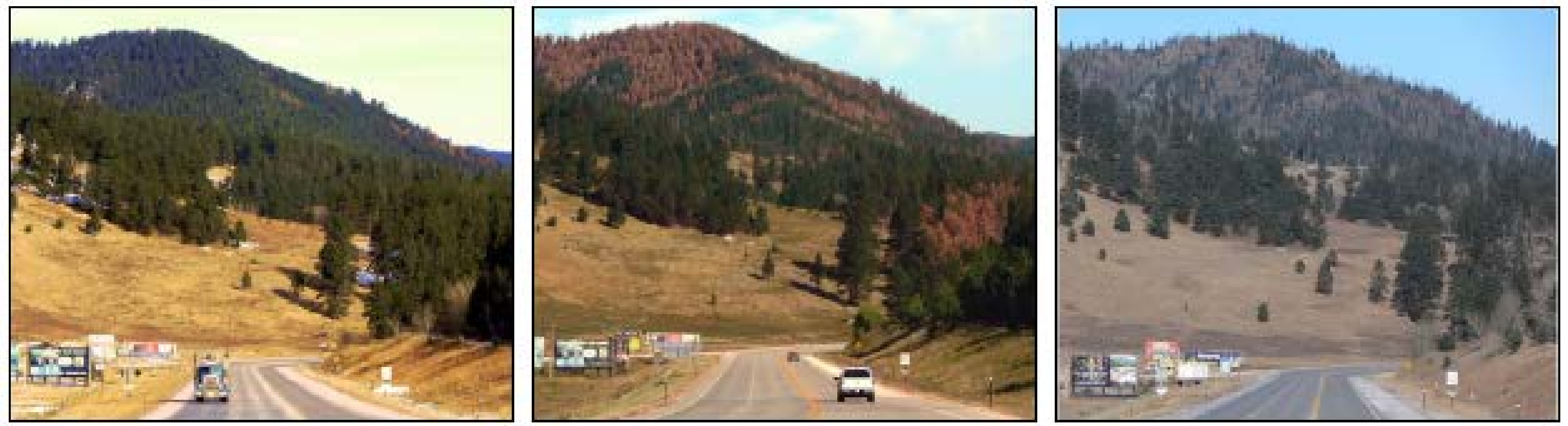

- 4,014 springs and 25 fens inventoried on NFS lands in the BHRL project area ( $>1.3$ million acres)

- Intensive field surveys have not occurred in all areas

- Partial Level I

- Figures may be low 


\section{Manti-La Sal Forest Plan Revision Assessment}

- Level I inventory

- Targeted grazing allotments and watersheds with specific management concerns

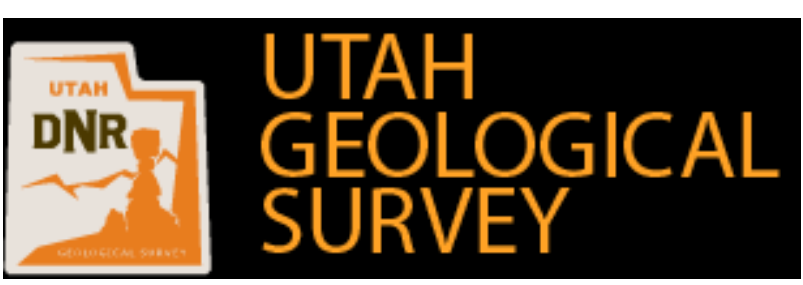

- Watering of livestock

- Water rights adjudication issues

- Potential impacts of subsurface coal

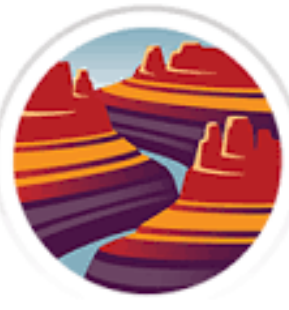

GRAND CANYON TRUST mining activities

- Colorado Natural Heritage Program (CNHP) developing a wetland map of the forest to identify 'potential fens'

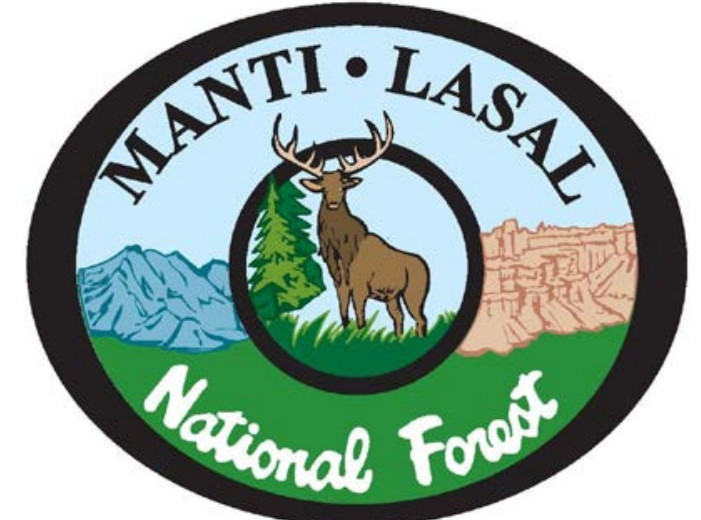


- Key ecosystem characteristics(KECs)

- Distribution of spring and wetland GDEs

- Composition of groundwater dependent biotic communities

- Water quantity

- Water quality

- Condition of spring runout channel

- Soil Quality and stability

- KECs align well with management indicators assessed during Level I

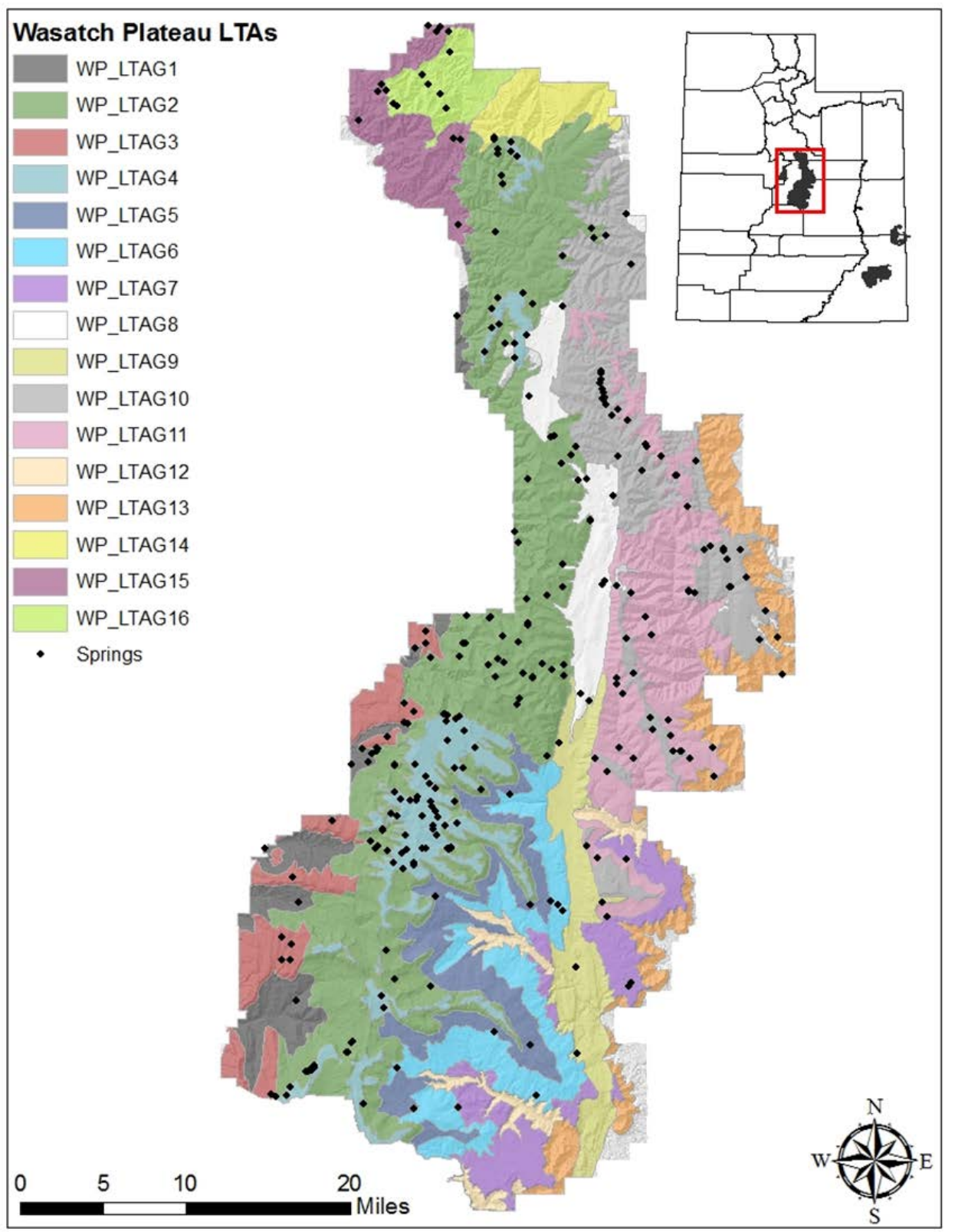

Distribution of documented springs

occurring in the Wasatch Plateau Landscape Type Associations (LTAs). 
- High densities of springs tend to occur in glaciated terrain, up to 0.004 springs/acre

- Condition of spring runout channel was outside NRV at many springs due to livestock use

- High densities of palustrine emergent wetlands occur in glaciated terrain and fault valleys

- No fens or peat-accumulating wetlands documented though likely present

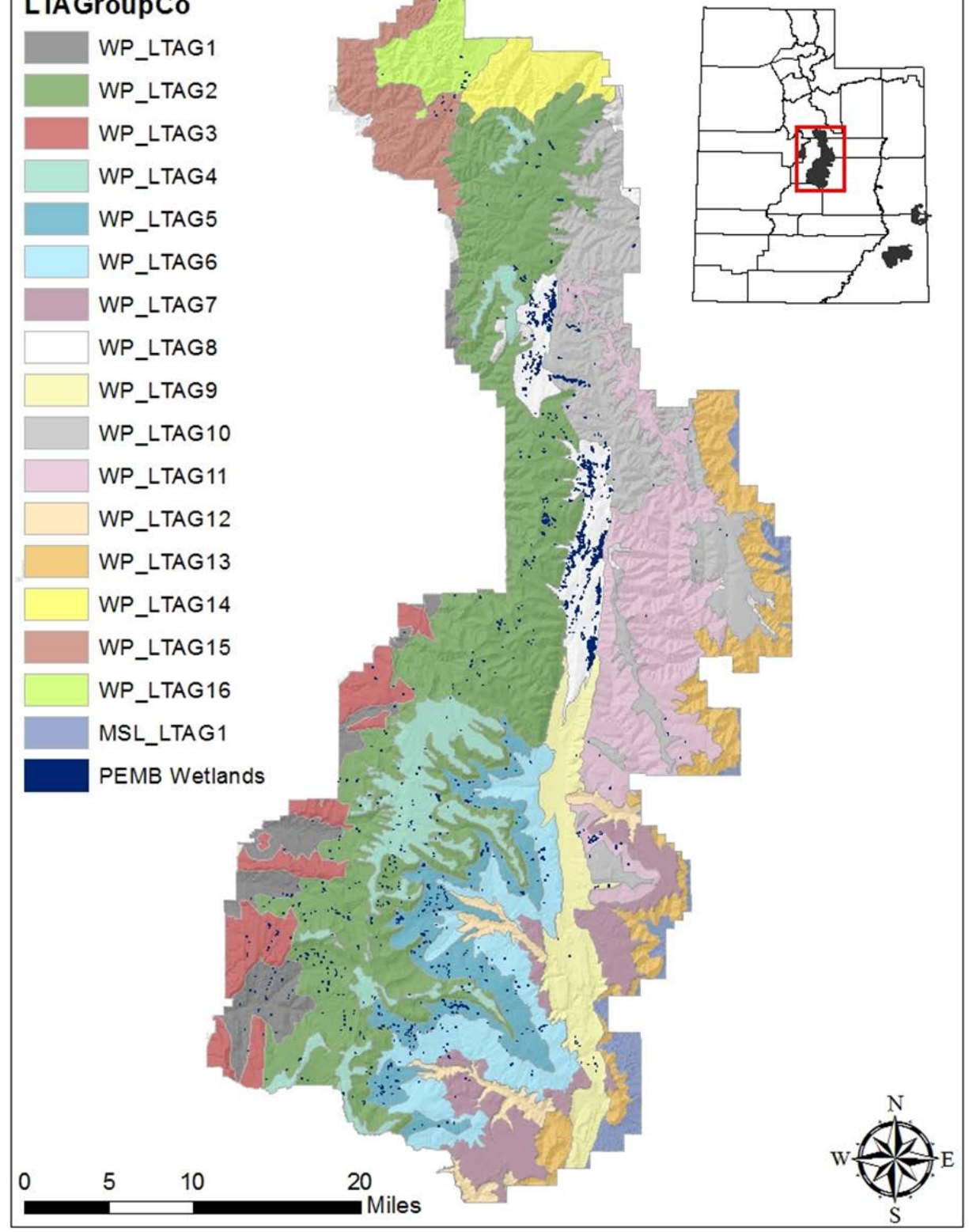

Distribution of palustrine emergent wetlands (PEMBs; Cowardin et al. 1979) on the Wasatch Plateau portion of the Manti-La Sal National forest 


\section{Ashley National Forest Plan Revision Assessment}

- 226 GDEs, mostly springs, have been characterized by forest staff since 2009 using Level I

- Targeted grazing allotments and watersheds with specific management concerns

- CNHP developing wetland map for Ashley NF

- Same KECs as Manti-La Sal

- Also looked for fen indicator species

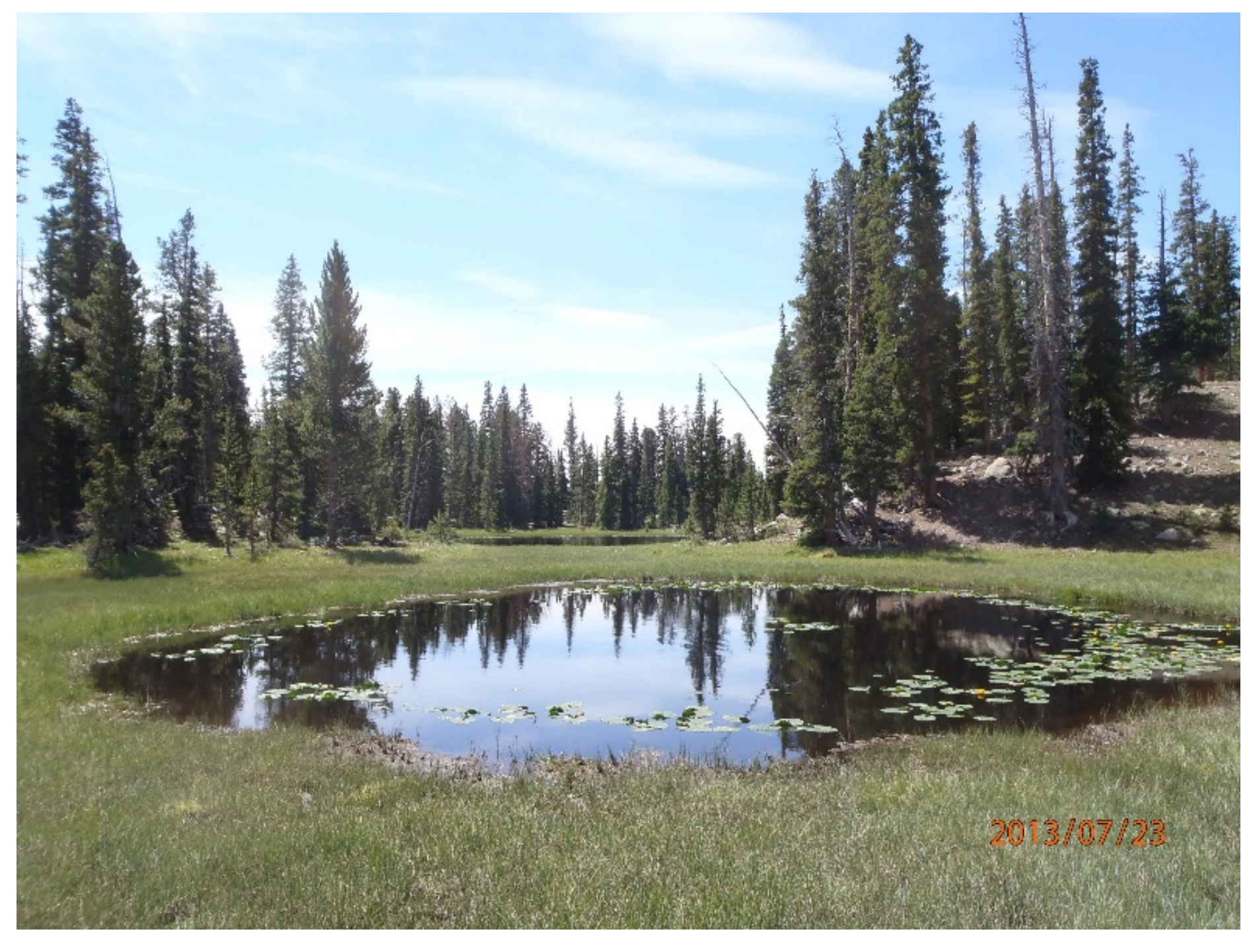




\section{Conclusions}

- Current information of GDEs on NFS lands is largely limited to targeted, fairly accessible sites

- Focused primarily on issues of pressing management concern

- More systematic inventories are needed

- Collected data often not entered into appropriate database(s)

- Forest Plan Revision efforts may offer best opportunities for forest-wide, comprehensive surveys 


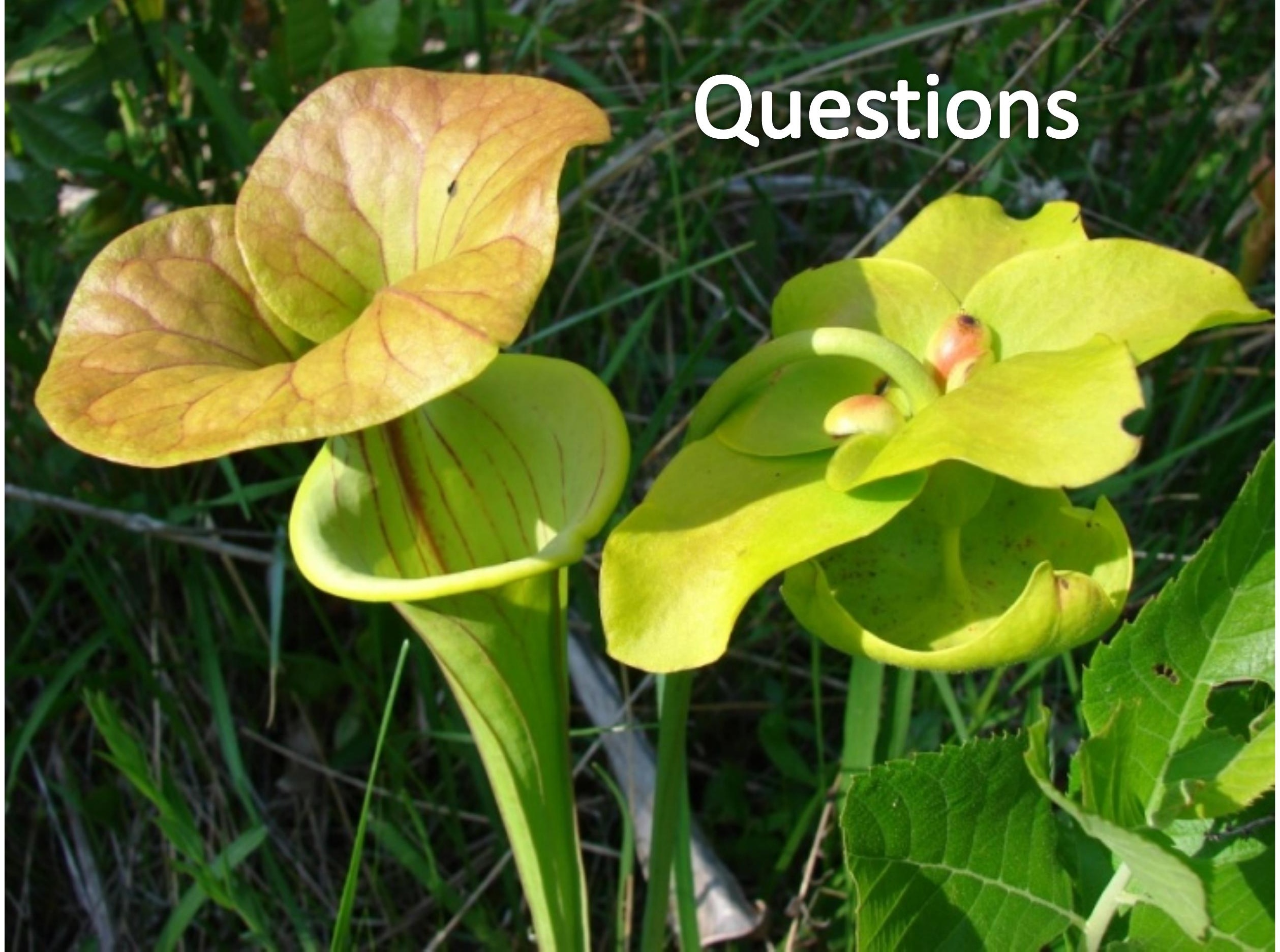

